\title{
PETA LOKASI PENANGKAPAN IKAN LEMURU DI SELAT BALI
}

\author{
Eko Susiloa,", I Made Kresnabayu ${ }^{a}$, I Gede Adi Swastan ${ }^{a}$

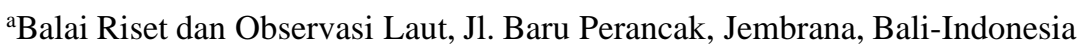 \\ *Koresponden penulis: ekosusilo@live.com
}

\begin{abstract}
Abstrak
Peta lokasi Penangkapan Ikan (Pelikan) Lemuru merupakan produk peta yang berisikan informasi spasil prediksi daerah penangkapan ikan pelagis kecil di perairan Selat Bali, khususnya ikan lemuru. Peta ini pada dasarnya memprediksi kelimpahan zooplankton, makanan utama jenis ikan pelagis kecil, termasuk ikan lemuru. Penelitian ini bertujuan untuk melakukan analisis spasial temporal prediksi kelimpahan zooplankton pada Pelikan Lemuru serta hubungannya dengan produksi perikanan di Selat Bali. Hasil analisis deret waktu menunjukkan kelimpahan zooplankton tertinggi terjadi pada akhir musim timur, yaitu antara bulan Agustus September dan terendah pada akhir periode musim barat (Februari - April). Variabilitas kelimpahan zooplankton pun tak dapat dilepaskan dari variabilitas kondisi laut. Anomali kondisi oseanografi pada tahun 2016 berdampak sangat signifikan terhadap kelimpahan zooplankton di Selat Bali. Kelimpahan zooplankton yang tinggi (>5.000 ind $\left./ \mathrm{m}^{3}\right)$ akan diikuti dengan volume produksi ikan yang cenderung tinggi pula. Namun sangat disayangkan, keberadaan Pelikan Lemuru belum dimanfaatkan secara optimal oleh pengguna. Aktivitas unduh Pelikan Lemuru rata-rata 4,33 kali unduh setiap bulan. Penyediaan data oseanografi bebas awan (free cloud) dan basis data penangkapan ikan yang valid dan akurat diperlukan untuk pengembangan Pelikan Lemuru maupun jenis ikan lainnya.
\end{abstract}

Kata kunci: citra satelit, generalized additive models, Pelikan Lemuru

Abstract

Lemuru Fishing Zone Map (Pelikan Lemuru) is a map that informs spatial predictions of small pelagic fishing areas in the Bali Strait, especially lemuru. Basically, Pelikan Lemuru predicts the abundance of zooplankton, the main diet of small pelagic fish, including lemuru. The aim of this study is to conduct a spatio-temporal analysis of prediction of zooplankton abundance from the Pelikan Lemuru model and its relationship with fish production in the Bali Strait. Here, the highest zooplankton abundance occurs at the end of the southeast monsoon, which is between August - September and the lowest is at the end of the northwest monsoon period (February - April). The variability of zooplankton abundance has a strong relationship with the oceanographic variability. Anomaly conditions occurred in 2016 had a significant impact on the abundance of zooplankton in the Bali Strait. The high abundance of zooplankton $\left(>5,000 \mathrm{ind} / \mathrm{m}^{3}\right)$ will be followed by the high volume of fish production. However, the existence of Pelikan Lemuru has not been used optimally by fishers with an average value of 4.33 downloads per month, respectively. The provision of free cloud oceanographic data and also a valid and accurate fishing database is needed for the development of Pelikan Lemuru and other fish species.

Keywords: generalized additive models, Pelikan Lemuru, satellite imagery

\section{PENDAHULUAN}

Selat Bali, sebuah perairan sempit yang memisahkan Pulau Jawa dan Pulau Bali, menyimpan menyimpan kekayaan dan keanekaragaman hayati laut yang melimpah. Salah satu jenis ikan yang menjadi primadona tangkapan nelayan yaitu ikan lemuru (Sardinella lemuru). Potensi lestari ikan lemuru di Selat Bali tercatat sekitar 25.107,32 ton/tahun, dengan nilai Jumlah Tangkapan Diperbolehkan (JTB) sebesar 20.085,86 ton per tahun [1]. Volume produksi tangkapan lemuru berkontribusi hingga mencapai 80 $90 \%$ dari total produksi perikanan pelagis di Selat Bali [2]. Melimpahnya ikan lemuru telah mendorong tumbuhnya industri pengolahan ikan kaleng dan tepung ikan yang tersebar di wilayah Pengambengan dan Muncar.

Namun dalam beberapa kurun waktu terakhir produksi ikan lemuru berfluktuasi dan cenderung menurun (Gambar 1). Pada tahun 2010, produksi ikan lemuru di kedua sentra pendaratan ikan tercatat mencapai lebih dari 
30.000 ton. Tren penurunan produksi berlangsung hingga mencapai puncaknya pada tahun 2016. Pelaku perikanan di Bali merasakan sekali dampak kelangkaan ikan lemuru di pasar. Sejak tahun 2016-2018 produksi ikan lemuru tidak sampai menembus angka 5.000 ton.

Fluktuasi produksi lemuru tak terlepas dengan kondisi oseanografi perairan yang dinamis dan adanya pengaruh proses upwelling yang terjadi di Samudra Hindia selatan Jawa dan Bali. Kondisi ini memicu terjadinya peningkatan kesuburan perairandan produktivitas ikan di Selat Bali [3]. Tren penurunan produksi yang terjadi belakangan ini sering dikaitkan dengan proses dampak perubahan iklim [4][5]. Selain menyebabkan kondisi cuaca laut yang tak menentu,perubahan iklim juga mempengaruhi habitat ikan, pola distribusi ikan, dan hasil tangkapan ikan. Perubahan suhu laut dan kesuburan ditengarai telah mempengaruhi pola distribusi dan daerah penangkapan ikan. Komposisi ikan hasil tangkapan nelayan di Selat Bali mengalami perubahan sejalan dengan variasi iklim. Pada saat periode El Nino, hasil tangkapan ikan didominasi oleh ikan lemuru. Sebaliknya pada periode La Nina, suhu laut menjadi lebih hangat yang menyebabkan ikan lemuru menghilang dan digantikan oleh kemunculan ikan tongkol dan ikan layang [2].

Dampaknya perubahan ini telah dirasakan oleh masyarakat pesisir, utamanya para pelaku kegiatan penangkapan ikan. Ketidakpastian daerah penangkapan ikan memaksa nelayan senantiasa berpindahpindah lokasi penangkapan ikan. Perilaku ini menyebabkan pemborosan bahan bakarminyak yang memicu biaya operasional penangkapan ikan cenderung tidak efisien [6]. Kondisi ini diperparah dengan kebiasaan nelayan di Selat Bali yang masih menggunakan teknik-teknik tradisional dalam penentuan daerah penangkapan ikan. Aktivitas penangkapan ikan sangat tergantung pada kelihaian "Juru Panggung", yaitu seorang nahkoda kapal yang dipandang memiliki pengalaman berburu ikan di Selat Bali. Belakangan nelayan menggunakan alat bantu berupa lampu untuk mengumpulkan gerombolan ikan [7].
Sebagai bentuk upaya adaptasi, Balai Riset dan Observasi Laut (BROL) telah memperkenalkan inovasi teknologi pendugaandaerah penangkapan ikan berbasis kondisi lingkungan di perairan Selat Bali. BROL secara rutin menerbitkan Peta lokasi Penangkapan Ikan (Pelikan) Lemuru, sebuah produk peta yang berisikan informasi mengenai prediksi harian kelimpahan zooplankton di perairan Selat Bali. Peta ini pada dasarnya memberikan informasi prediksi kelimpahan zooplankton, makanan utama jenis ikan pelagis kecil, termasuk ikan lemuru [8]. Penelitian ini bertujuan untuk melakukan analisis spasial temporal prediksi kelimpahan zooplankton pada Pelikan Lemuru serta hubungannya dengan produksi perikanan di Selat Bali.

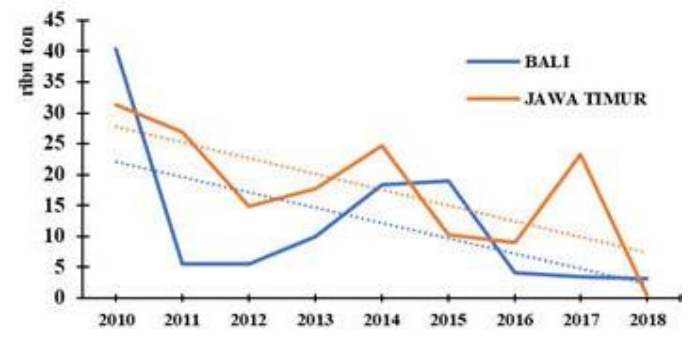

Gambar 1. Produksi ikan lemuru di Selat Bali tahun 2010-2018

(sumber: diolah dari statistik.kkp.go.id)

\section{METODE}

\section{Prediksi Kelimpahan Zooplankton}

Sebaran spasial dan temporal kelimpahan zooplankton diprediksi berdasarkan parameter oseanografi hasil perekaman citra satelit AquaMODIS (Moderate Resolution Imaging Spectroradiometer) Standar Mapped Image Level 3 melalui pendekatan statistik generalized additive models dengan persamaan sebagai berikut [8]:

$\operatorname{sqrt}(\mathrm{zoo}+1)=\alpha+\mathrm{s}(\mathrm{SST})+\mathrm{s}(\mathrm{SSC})+\mathrm{s}(\mathrm{PAR})+\varepsilon$

dimana,

zoo $=$ kelimpahan zooplankton $\left(\mathrm{ind} / \mathrm{m}^{3}\right), \mathrm{s}=$ smoothing factors, chl = konsentrasi klorofil-a $(\mathrm{mg} / \mathrm{m} 3), \mathrm{spl}=$ suhu permukaan laut $\left({ }^{\circ} \mathrm{C}\right)$, dan par $=$ photosynthetically available radiation (einstein/m2/day). 


\section{Data Produksi Ikan}

Data produksi ikan diperoleh dari Dinas Perhubungan, Kelautan dan Perikanan Kabupaten Jembrana. Pendaratan ikan di TPI Pengambengan selama periode periode tahun 2008-2015 umumnya didominasi oleh 3 jenis ikan yaitu lemuru (Sardinella lemuru), tongkol (Auxis sp.) dan layang (Decapterus sp.).

\section{HASIL DAN PEMBAHASAN}

\section{Variabilitas lingkungan laut Selat Bali}

Hasil analisis data citra Aqua Modis menunjukkan variabilitas suhu permukaan laut (SPL) mengikuti siklus monsoon, yaitu musim timur (southeast monsoon) dan musim barat (northwest monsoon). Musim timur terjadi pada bulan Juni - Agustus, sedangkan musim barat terjadi pada bulan Desember Februari. Pada periode musim barat, SPL cenderung lebih hangat daripada periode musim timur. Peningkatan SPL terjadi mulai bulan November hingga mencapai suhu tertinggi pada bulan Maret. Sedangkan trend penurunan SPL mulai terlihat sejak awal musim timur (April) dengan nilai terendah pada bulan Agustus. Kondisi SPL di perairan Selat Bali pada tahun 2017 cenderung mengikuti nilai SPL klimatologis (20032016). Pada awal tahun kondisi laut cenderung lebih hangat dibandingkan kondisi beberapa tahun sebelumnya. Namun pada periode musim timur kondisi laut cenderung lebih dingin, walaupun nilai SPL terendah terlihat masih sama dengan sama dengan periode tahun sebelumnya yaitu pada kisaran $25,9^{\circ} \mathrm{C}$.

Pola yang sama juga ditunjukkan oleh variabilitas konsentrasi klorofil-a (CHL), yaitu mengikuti pola monsoon. Pada umumnya variabilitas CHL berbanding terbalik dengan variabilitas SPL. Hasil analisis deret waktu citra klorofil-a menunjukkan konsentrasi klorofil-a tertinggi terekam pada periode musim timur. Sementara pada musim yang barat konsentrasi klorofil-a cenderung lebih rendah. Konsentrasi klorofil-a pada tahun 2017 pun cenderung mengikuti nilai konsentrasi klorofila klimatologis. Namun nilainya cenderung lebih tinggi dibandingkan periode sebelumnya, yaitu mencapai $1,6 \mathrm{mg} / \mathrm{m}^{3}$ pada periode waktu yang sama.

Kondisi anomali SPL dan konsentrasi klorofil-a nampak pada tahun 2016. Kondisi laut cenderung lebih hangat $\left(>28^{\circ} \mathrm{C}\right)$ pada musim timur, yang dikenal sebagai puncak proses upwelling. Demikian pula halnya dengan konsentrasi klorofil-a yang menunjukkan nilai yang rendah dibandingkan pada periode musim timur yang sama tahuntahun sebelumnya $\left(<0,6 \mathrm{mg} / \mathrm{m}^{3}\right)$. Hal ini menyebabkan kelimpahan zooplankton pun mengalami penurunan. Pasokan makanan yang terbatas menyebabkan pertumbuhan zooplankton juga terhambat. Namun belum diketahui penyebab pasti kenapa pada periode tahun tersebut terjadi kondisi demikian. Beberapa hipotesis menyebutkan adanya pengaruh iklim regional terhadap intensitas upwelling di Samudera Hindia Selatan Jawa Bali.

Photosynthetically available radiation (PAR), aliran energi matahari dalam kisaran spektrum 400-700 nm. PAR yang mencapai permukaan laut, diketahui berperan mengontrol pertumbuhan fitoplankton dan perkembangan krustasea, ikan, dan konsumen lain [9]. Distribusi spasial PAR tergantung pada siklus musim dan menunjukkan siklus musiman yang luar biasa. Pergerakan semu matahari menjadi faktor penentu tinggi rendahnya PAR di Selat Bali. Pada saat matahari berada di belahan bumi Selatan, nilai PAR di Selat Bali cenderung meningkat. Sebaliknya, seiring dengan bergesernya matahari ke belahan bumi utara, nilai PAR berangsur mengalamipenurunan. 
Sea Surface Temperature ('C)

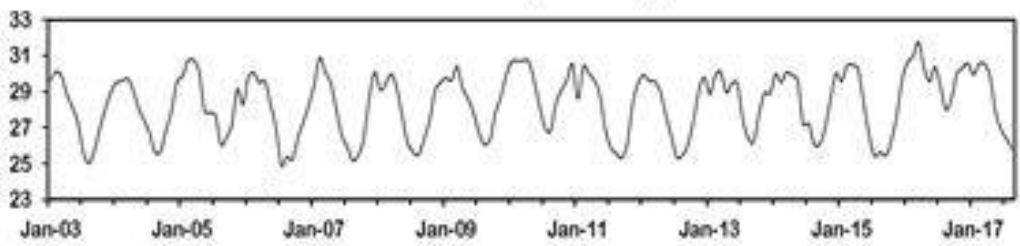

Chlorophyll-a Concentration (mgim3)

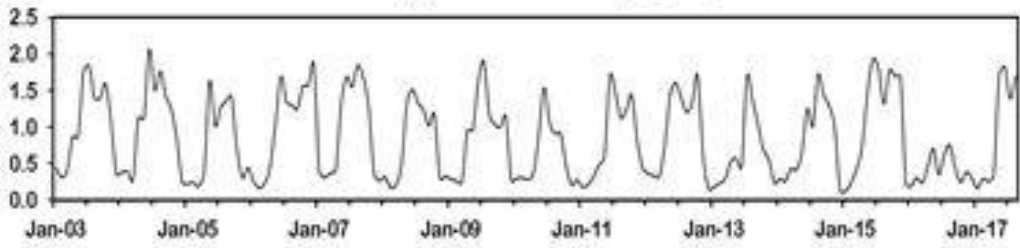

Photosynthetically Active Radiation (einsten/m²/day)

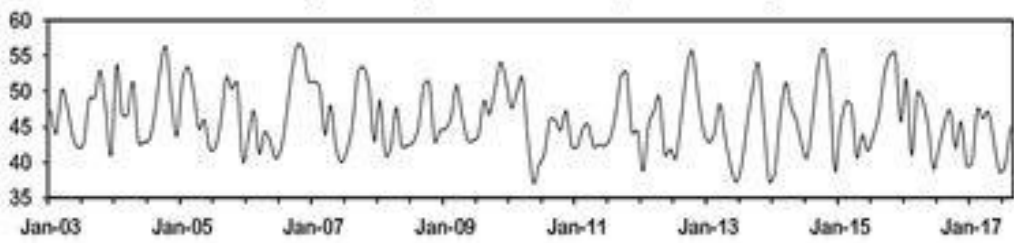

Zooplankton Abudance $(x 1.000$ ind $/ \mathrm{m} 3)$

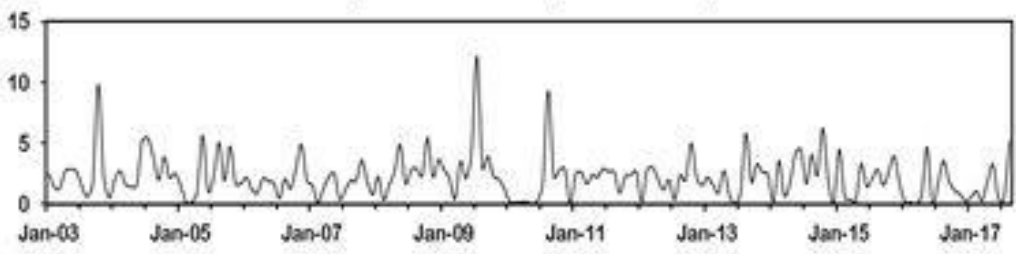

Gambar 2. Analisis Deret Waktu Tahun 2003-2017

Kondisi laut yang dingin pada periode musim timur mengindikasikan adanya pengaruh upwelling yang terjadi perairan Samudra Hindia Selatan Jawa Bali. Arus laut membawa massa air yang dingin tersebut memasuki perairan Selat Bali. Proses indirect upwelling ini ditandai SPL yang lebih rendah dari $28^{\circ} \mathrm{C}$ [3]. Hal ini sejalan dengan hasil penelitian yang menyebutkan distribusi spasial SPL di perairan Selat Bali cenderung lebih hangat bila dibandingkan dengan bagian selatan Selat Bali pada musim timur. Massaair dengan suhu rendah terlihat di bagian selatan perairan dengan nilai berkisar antara 26,78$26,77^{\circ} \mathrm{C}[10]$. Daerah upwelling adalah daerah potensial untuk kegiatan perikanan, karena kaya akan sumber makanan untuk keberlangsungan larva, juvenil dan ikan dewasa. Melimpahnya sumber makanan tidak terlepas dari pasokan unsur hara yang tinggi pada lapisan fotik. Ketersediaan unsur hara tersebut memicu pertumbuhan fitoplankton secara masif. Berperan sebagai produsen primer pada rantai makanan ekosistem perairan, pertumbuhan fitoplankton yangtinggi secara simultan akan memicu pertumbuhan zooplankton dan menjadi daya tarik bagi ikan untuk berkumpul di perairan Selat Bali. Melimpahnya fitoplankton pada ekosistem laut dapat direpresentasikan dengan nilai konsentrasi klorofil-a. Pada saat terjadi upwelling nilai konsentrasi klorofil-a dapat melebihi $0,8 \mathrm{mg} / \mathrm{m}^{3}$ [3]. 
Variabilitas kelimpahan zooplankton pun tak dapat dilepaskan dari variabilitas kondisi laut. Hasil analisis deret waktu menunjukkan pada umumnya kelimpahan zooplankton tertinggi terjadi pada akhir musim timur, yaitu antara bulan Agustus - September dan terendah pada akhir periode musim barat (Februari - April). Nilai kelimpahaan zooplankton yang tinggi terjadi pada tahun 2003, 2009, dan 2010.

Proses upwelling menyebabkan pengadukan perairan sehingga perairan semain subur dan mendorong pertumbuhan fitoplankton. Kondisi ini mendorong tumbuh kembang zooplankton di perairan. Namun belum ditemukan referensi yang memadai mengenai perubahan struktur komunitas zooplankton di Selat Bali dan responnya terhadap perubahan kondisi oseanografi. Informasi ini penting artinya guna menjelaskan interaksi antara perubahan struktur komunitas zooplankton dengan kebiasaan makan ikan lemuru maupun jenis ikan pelagis lainnya.

\section{Interaksi kelimpahan zooplankton dan produksi ikan}

Hasil analisis deret waktu kelimpahan zooplankton dan volume pendaratan ikan di TPI Pengambengan periode tahun 2008-2017 menunjukkan bahwa kelimpahan zooplankton yang tinggi $\left(>5.000 \mathrm{ind} / \mathrm{m}^{3}\right)$ diikuti dengan volume produksi ikan yang cenderung tinggi pula (Gambar 3). Volume pendaratan lemuru yang tinggi pada akhir 2008 ( 2.800 ton) bersesuai dengan melimpahnya zooplankton pada periode bulan Oktober $\left(5.460 \mathrm{ind} / \mathrm{m}^{3}\right)$. Tingginya kelimpahan zooplankton pada periode Juli $2009\left(12.141 \mathrm{ind} / \mathrm{m}^{3}\right)$ mendorong melimpahnya volume produksi lemuru pada periode bulan selanjutnya. Tidak hanya ikan lemuru, pendaratan ikan tongkol dan layang juga mengalami peningkatan yang cukup signifikan dibandingkan periode yang sama pada tahun sebelumnya. Volume produksi yang tinggi bertahan hingga beberapa bulan sampai memasuki awal tahun 2010. Namun hal ini tidak diikuti dengan kelimpahan zooplankton yang tinggi sepanjang periode tersebut.

Kelimpahan zooplankton yang cenderung stabil pada tahun 2011 bersesuaian dengan volume pendaratan ikan tongkol dan layang yang tinggi (500 - 700 ton). Pada periode tahun 2011-2013 volume produksi lemuru cenderung rendah dan sedikit sekali mengalami peningkatan pada akhir 2013,yang tentu saja bersesuaian dengan melimpahnya zooplankton pada periode tersebut. Menjelang akhir tahun 2014 produksi mengalami peningkatan yang signifikan ( 2.600 ton) yang dipicu oleh tingginya zooplankton pada periode yangsama.

Anomali volume pendaratan ikan yang tinggi pada tahun 2010 yang tidak bersesuai dengan kelimpahan zooplankton patut untuk dikaji lebih mendalam. Hal ini dimungkinkan adanya pengaruh iklim regional yang diduga mempengaruhi migrasi ikan ke perairan Selat Bali secara besar-besaran. Namun ketersediaan makanan (zooplankton) yang terbatas diduga menjadi penyebab tingginya rasio mortalitas ikan lemuru. Kondisi ini menyebabkan kegagalan rekrutmen stok dan menurunkan volume produksi pada tahuntahun berikutnya.

Keterkaitan antara ketersediaan planton dan kelimpahan ikan lemuru di Selat Bali dapat ditinjau dari kebiasaan makan ikan lemuru itu sendiri. Lemuru, termasuk kelompok ikan pemakan plankton. Namun demikian lemuru cenderung memilih makanannya. Komposisi anatara fiplankton dan zooplankton bervaariasi menurut musim dan masa pertumbuhannya [11][12]. Pada era 80-an diketahui komposisi makanan ikan lemuru didominasi oleh zooplankton [13]. Komposisi makanan lemuru mengalami perubahan dari fitoplankton dan ke zooplankton akibat pengaruh musim. Pada musim timur, saat proses upwellilng menguat, lemuru dominan memakan fitoplankton, sedangkan pada musim barat makanan lemuru didominasi olehkelompok zooplankton [14]. Belakangan diketahui bahwa fitoplankton, khususnya dari kelas Cyanophyceae dan Bacillariophyceae merupakan yang paling banyak dimakan oleh ikan lemuru [11]. 

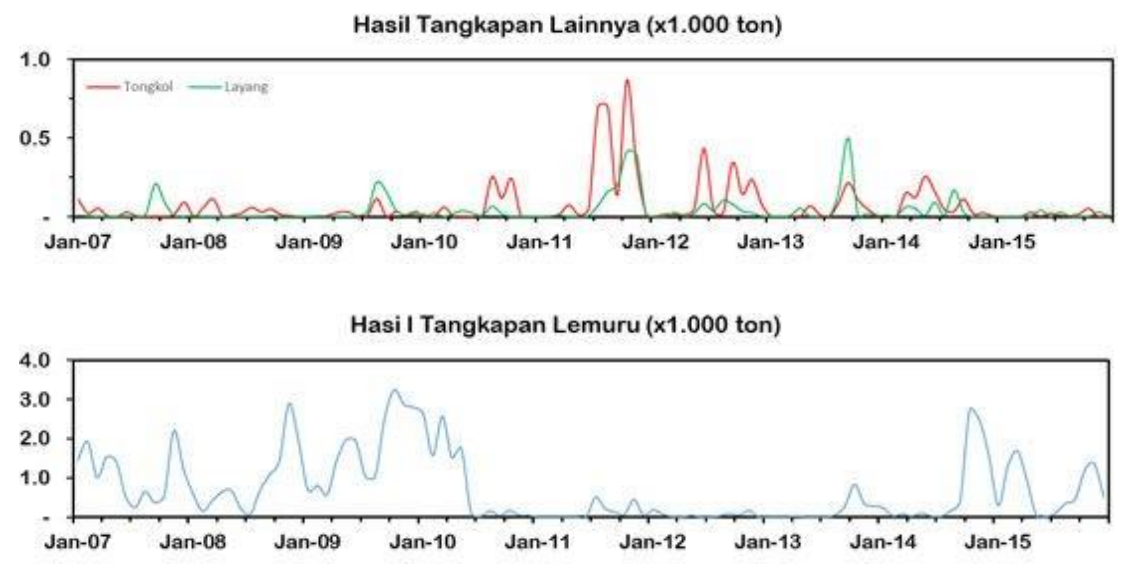

Zooplankton Abudance ( $\times 1.000 \mathrm{ind} / \mathrm{m} 3)$

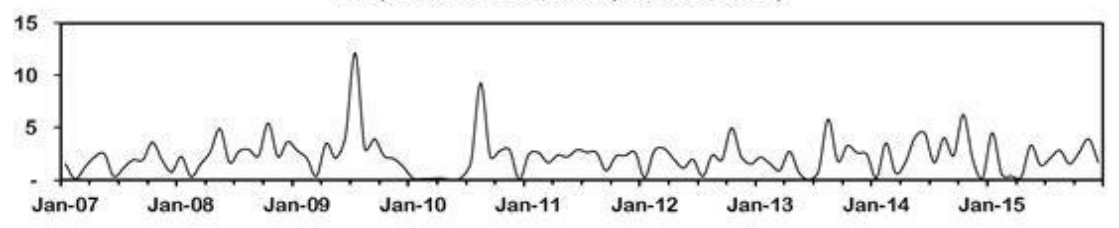

Gambar 3. Hubungan Kelimpahan Zooplankton dengan hasil tangkapan ikan di PPN Pengambengan (2007-2015)

\section{Diseminasi}

Pelikan Lemuru disebarkan melalui aplikasi berbasis website dan android. BROL mengembangkan SIDIK, yaitu aplikasiberbasis di server website yang dapat diakses melalui komputer atau gadget pada laman www.bpol.litbang.kkp.go.id/sidik. Namun sangat disayangkan tingkat adopsi nelayan terhadap peta ini masih rendah. Sejak pertama kali diperkenalkan 5 tahun yang lalu, peta ini belum sepenuhnya dimanfaatkan secara optimal oleh nelayan. Hasil pengukuran aktivitas pengguna SIDIK tahun 2020 menunjukkan jumlah peta yang diterbitkan berkorelasi dengan jumlah peta diunduh (Gambar 4). Hanya saja jumlah aktivitas unduh oleh pengguna setiap bulannya yang masih sangat rendah dengan nilai rata-rata 4,33 kali. Aktivitas unduh terbanyak terjadi pada bulan Juli 2020 sebanyak 17 kali,selebihnya pada bulan lainnya hanya diunduh tidak lebih dari 5 kali. Hal ini dimungkinkan karena aksesibilitas nelayan terhadap aplikasi SIDIK masih sangat terbatas.

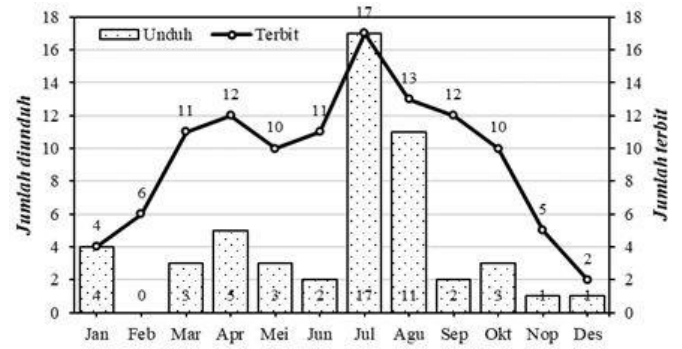

Gambar 4. Keragaan pemanfaatan Pelikan Lemurumelalui aplikasi SIDIK tahun 2020

Oleh karenanya BROL bersama mitra mengembangan Laut Nusantara, yaitu aplikasi berbasis android yang dapat diakses melalui perangkat telepon pintar (smartphone).Melalui aplikasi ini, nelayan diberikan kemudahan mengakses Pelikan Lemuru sehingga perencanaan aktivitas penangkapan ikan dapat dilakukan dengan lebih baik, mulai menentukan secara mandiri lokasi penangkapan ikan terdekat, estimasi kebutuhan Bahan Bakar Minyak (BBM) hingga estimasi harga jual di pelabuhan. Nelayan juga diberikan informasi cuaca laut 
terkini sehingga dapat meningkatkan kewaspadaan selama bekerja di laut.

\section{Pengembangan ke Depan}

Letak Indonesia yang berada di daerah tropis berimbas tingginya cakupan awan pada data citra satelit yang selama ini digunakan sebagai masukan model prediksi. Pada musim penghujan, jumlah produksi peta menurun sangat signifikan (Gambar). Hal ini menyebabkan informasi peta tidak dapat disampaikan kepada pengguna secara komprehensif. Oleh karenanya penyediaandata oseanografi bebas awan (free cloud) baik dari citra satelit maupun keluaran model numerik menjadi prioritas riset di Balai Riset dan Observasi Laut ke depannya. Sejumlah data citra yang berpotensi digunakan antara lain Multi-sensor Ultra-high Resolution (MUR) SST dan HIMAWARI-8.

Pengembangan peta prediksi jenis ikan lainnya juga menjadi fokus riset berikutnya. Mengingat selain ikan lemuru, Selat Bali juga memiliki berbagai jenis ikan lainnya seperti tongkol (Euthynnus sp.), layang (Decapterus spp), slengseng (Scomber australasicus), banyar (Rastrelliger sp.), dan tembang (Sardinella fimbriata). Namun untuk dapat menghasilkan peta prediksi jenis ikan tersebut diperlukan basis data (logbook) penangkapan ikan yang valid dan akurat. Sayangnya saat ini proses pencatatan data hasil tangkapan di Selat Bali belum dilaksanakan dengan baik. Nelayan belum menggunakan perangkat navigasi dalam aktivitas penangkapan ikan, sehingga sulit untuk mendapatkan informasi keruangannya. Oleh karena perlu dibangun sistem pelacakan (tracking) kapal ikan untuk memantau pergerakan kapal dan identifikasi daerah penangkapan ikan. Selanjutnya perlu dibangun program pencatatan hasil tangkapan secara ilmiah (scientific observer) yang berkelanjutan.

\section{KESIMPULAN}

Variabilitas kelimpahan zooplankton di Selat Bali tak dapat dilepaskan dari variabilitas kondisi lingkungan laut, yang bervariasi mengikuti pola sistem monsoon.
Pengaruh iklim regional diduga kuat turut mempengaruhi kondisi lingkungan laut. Anomali kondisi lingkungan laut pada tahun 2016 berdampak sangat signifikan terhadap kelimpahan zooplankton di Selat Bali. Umumnya kelimpahan zooplankton yang tinggi (>5.000 ind $/ \mathrm{m}^{3}$ ) akan diikuti dengan peningkatan volume produksi ikan. Namun keberadaan Pelikan Lemuru belum dimanfaatkan secara optimal oleh nelayan dengan nilai rata-rata unduhan peta per bulan hanya 4,33. Penyediaan data oseanografi bebas awan (free cloud) dan basis data penangkapan ikan yang valid dan akurat diperlukan untuk pengembangan PelikanLemuru maupun jenis ikan lainnya.

\section{UCAPAN TERIMA KASIH}

Penelitian ini merupakan bagian dari kegiatan Pengembangan Peta Prakiraan Daerah Penangkapan Ikan (PPDPI) yang dibiayai oleh DIPA Balai Riset dan Observasi Laut tahun anggaran 2018. Penulis mengucapkan terima kasih kepada I Gede Budhiadnya (Dinas Perhubungan Kelautandan Perikanan Kabupaten Jembrana) yang telah membantu proses pengumpulan data produksi perikanan pelagis di tempat pendaratan ikan, serta kepada NASA Goddard Space Flight Center, Ocean Ecology Laboratory, Ocean Biology Processing Group yang telah menyediakan dan memberikan akses data citra oceancolor dalam penelitian ini. Tak lupa pula kepada segenap Editor dan Reviewer atas masukkan untuk perbaikan subtansi maupun redaksi karya tulis ilmiah ini.

\section{DAFTAR PUSTAKA}

[1] S. W. Nugraha, A. Ghofar, and S.Wijaya, "Monitoring perikanan lemuru di perairan Selat Bali," J. Maquares, vol. 7, no. 1, hal. 130-140, 2018.

[2] A. Sartimbul, E. Rohadi, D. Yona, E. Yuli H., A. Bakar Sambah, and J. Arleston, "Change in Species Composition and Its Implication on 
Climate Variation in Bali Strait: Case Study in 2006 and 2010," in 3rd International Conference on Fisheries and Aquaculture, 2016, pp. 1-7.

[3] N. Hendiarti et al., "Seasonal variation of pelagic fish catch around java," Oceanography, vol. 18, no. SPL.ISS. 4, pp. 114-123, 2005.

[4] R. Puspasari, P. F. Rachmawati, S. Bali, and S. Makassar, "Analisis Kerentanan Jenis Ikan Pelagis Kecil Di Perairan Selat Bali," J.Lit.Perikan.Ind., vol. 22, no. 1, pp. 33-42, 2016.

[5] R. Puspasari, P. F. Rachmawati, and U. Muawanah, "Climate variability impact on Bali sardine fishery: Ecology and fisheries perspective," Fish. Manag. Ecol., vol. 26, no. 6, pp. 540-547, Dec. 2019.

[6] E. S. Wiyono, "Analisis Efisiensi Teknis Penangkapan Ikan Menggunakan Alat Tangkap Purse Seine Di Muncar, Jawa Timur," J. Teknol. Ind. Pertan., vol. 22, no. 3, pp. 164-172, 2013.

[7] D. Setyohadi and D. G. R. Wiadnya, Pengkajian Stok dan Dinamika Populasi Ikan Lemuru. Malang: UB Press, 2018.

[8] E. Susilo and T. Arief Wibawa, "Pemanfaatan Data Satelit Oseanografi Untuk Memprediksi Daerah Penangkapan Ikan Lemuru Berbasis Rantai Makanan Dan Pendekatan Statistik Gam," J. Kelaut. Nas., vol. 11, no. 2, p. 77, 2016
[9] I. S. Robinson, Discovering the Ocean from Space. Berlin, Heidelberg: Springer-Verlag Berlin Heidelberg,2010.

[10] W. E. Rintaka, A. Setiawan, E. Susilo, and M. Trenggono, "Variasi Sebaran Suhu, Salinitas Dan Klorofil Terhadap Jumlah Tangkapan Lemuru Di Perairan Selat Bali Saat Muson Tenggara," in Pertemuan Ilmiah Nasional Tahunan X ISOI, 2014, pp. 20-31.

[11] N. D. Pertami, M. F. Rahardjo, A. Damar, and I. W. Nurjaya, "Makanan dan kebiasaan makan ikan lemuru, Sardinella lemuru Bleeker, 1853 di perairan Selat Bali," J. Iktiologi Indones., vol. 19, no. 1, pp. 143-155, 2019.

[12] E. Y. Herawati, A. Sartimbul, and R. I. Khasanah, "Kelimpahan dan keanekaragaman plankton di daerah penangkapan ikan lemuru (Sardinella lemuru) di Selat Bali," Pertemuan Ilmiah Nasional Tahunan X ISOI 2013. Ikatan Sarjana Oseanologi Indonesia (ISOI), Jakarta, pp. 343-352, 2014.

[13] Burhanuddin, M. Hutomo, S. Martosewojo, and R. Moeljanto, Sumber Daya Ikan Lemuru. Jakarta: LIPI, 1984.

[14] R. I. Khasanah, A. Sartimbul, and E. Y. Herawati, "Komposisi isi lambung ikan lemuru (Sardinella lemuru) di Perairan Selat Bali," in Prosiding Seminar Nasional Ikan ke 8, 2014, vol. 2, no.1962, pp. 315-322. 